\title{
Charlotte Hempel
}

\section{The Community Rules from Qumran}

\section{A Commentary}

[Die Gemeinderegeln von Qumran. Ein Kommentar.]

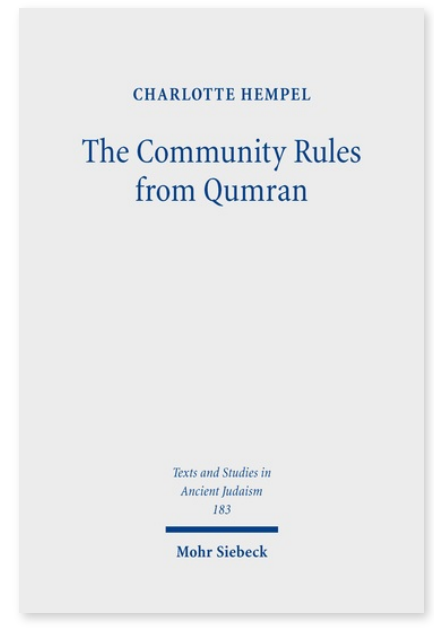

2020. XXV, 346 pages. TSAJ 183

ISBN 978-3-16-157026-1

cloth $169,00 €$

ISBN 978-3-16-157027-8

eBook PDF 169,00€
Published in English.

In this volume, Charlotte Hempel offers the first comprehensive commentary on all twelve ancient manuscripts of the Rules of the Community, works which contain the most important descriptions of the organisation and values ascribed to the movement associated with the Dead Sea Scrolls. The best preserved copy of this work (1QS) was one of the first scrolls to be published and has long dominated the scholarly assessment of the Rules. The approach adopted in this commentary is to capture the distinctive nature of each of the manuscripts based on a synoptic translation that presents all the manuscripts at a glance. Textual notes and Commentary deal with the picture derived from all preserved manuscripts. The publication of the Cave 4 manuscripts in 1998 can be likened to a volcanic eruption that challenged prevalent notions of the Community Rules that were founded on the quasi-archetypal status of the Cave 1 copy published in 1951. Since then the smoke has lifted and, as the pieces have begun to settle, we see green shoots emerging in the scholarly debate.. This commentary embraces the post-volcanic landscape of the Community Rules, which is carefully sifted for clues to establish a fresh reading of the material in conversation with the latest research on the Scrolls. The evidence suggests that some of the practices described as the beating heart of the movement's organization reflect the aspirations of a privileged sub-elite from the late Second Temple Period.

Charlotte Hempel Born 1966; 1991 BA; 1995 PhD; 1995-99 Post-Doctoral Research Fellowships at the Universities of Birmingham and Cambridge; 1999-2004 Maternity Career Break; 2005 Research Fellow, 2008 Senior Research Fellow, 2010 Senior Lecturer, 2013 Reader and since 2016 Professor of Hebrew Bible and Second Temple Judaism at the University of Birmingham, UK.

https://orcid.org/0000-0002-8106-1627

\section{Order now:}

https://www.mohrsiebeck.com/en/book/the-community-rules-from-qumran-9783161570261?no_cache=1 order@mohrsiebeck.com

Phone: +49 (0)7071-923-17

Fax: $+49(0) 7071-51104$ 